\title{
Competition Gaps of Tomatoes' Industries in Cameron Highland, Malaysia
}

\author{
Hengky, S. H. \\ Associate Professor, Triguna School of Economics, Director, SHINE Institute \\ E-mail: hengky_halim@yahoo.com.au
}

Received: October 29, 2016

Accepted: November 29, 2016

doi:10.5296/ber.v6i2.10408

URL: http://dx.doi.org/10.5296/ber.v6i2.10408

\begin{abstract}
Currently, the price range of tomatoes is a great loss to the producers or tomato growers in Malaysia. Meanwhile, in terms of the purchasing power of consumers, Malaysia is one of the more prosperous in the countries in Asia with a GDP per capita of about US \$10,876 in 2016. In reducing the width of the tomato price range, it needs of industrial competition analysis or market tomatoes in Cameron Highland pertinent for the issue. The aim of this study was to identify the tomato industry competition in Cameron Highland, Malaysia, and it was conducted in three (3) stages: a) in this stage, carried out literature studies and searches related and related information to the players, organization, customer, and supplier market tomatoes, b) the collection of data and information according to the research objectives, and c) conduct focus group discussions with the topic a tomato industry competition and tabulation of data. Results of the study found that the tomato industry competition is quite significant in Cameron Highland. The threat of substitute product's tomatoes from other regions or import is very dominant. Nearly 60 percent of tomatoes from Thailand supplied to Malaysia. The indicators, tomatoes are very easily available in the entire super market and traditional market in the peninsula Malaysia. Meanwhile, the State Thailand is a threat from new entrants who have high accessibility of land, which is between Bukit Kayu Hitam (Malaysia) and Sadao (Thailand). On the other hand, distributors have greater bargaining power in determining the market price because he is dealing with a large number of intermediaries to be selected. Industry competition structure above causes the position of farmers locked in power distributor or intermediary is dominant. Meanwhile, developments in information technology become an opportunity for farmers to get information about the price of tomatoes at the farmers directly in connection to the supermarket or to the market. Indirectly, the role of intermediaries can be reduced. Thus, the price of tomatoes is not manipulated by them. In addition, farmers can plan for the future market production.
\end{abstract}

Keywords: Industrial competitions, Bargaining power of distributors, Bargaining power of 
customers

\section{Introduction}

Tomatoes are a vegetable similar type of fruit that has a short lifespan and into food that meets human needs in a different world. These plants come from South American countries, and now the plant has been expanded to grow in many tropical countries. The scientific name for the tomato is Lycopersicon cycopersicum, and comes from the family Solanaceae. Tomato plants are divided into two major groups, namely growing up and growing creeper. The differences also exist in the fruit characteristics that became the basis of differences it's cultivar.

The main production of tomatoes in Malaysia's country mostly comes from the Cameron Highland, which has a land area of lowland. In addition, other areas that produce tomato is in the area of Johor. Most of these plants are cultivated to meet the demand of domestic market and partly exported to Singapore. The country of Malaysia also imported 4000 tons of tomato products per annum for the purposes of the local-population. Local production is only sufficient for the consumption of fresh fruit.

Currently, fluctuation in the price of tomatoes is very large, from USD 0.3 to USD 1 per $\mathrm{kg}$. Fluctuation in the price of tomatoes was a great loss to the producers or tomato farmers in Malaysia. Meanwhile, the tomato industry associations in Malaysia providing active-consumer activity data and significantly, which will continue to follow the changes in their food consumption patterns, leading to increased consumption of imported food and beverages. To reduce the width of the range of the price of tomatoes, it needs of industrial competition analysis or market tomatoes in Cameron Highland relevant to the issue.

Previously, in terms of purchasing power of consumers, Malaysia was one of the more affluent among the countries in Asia with a GDP per capita of about US \$10,876 in 2016 (Trading Economics, 2016). The economy grew consisting of the potential of agriculture, services and manufacturing industries. Economy continues to grow well, and is expected to grow 5.4 percent in 2014 (Nasir \& Nawawi, 2014; and Hoh, 2014) and in 2015 is expected to grow 4.6 percent.

The purpose of this study is to identify a gap's competition of tomato industry in Cameron Highland, Malaysia.

\section{Literature Review}

\subsection{Analysis of Industrial Environment}

Analysis of Industrial Environment According to Porter (2008) and Mathooko \& Ogutu, (2015) competition changes that occur in the industrial environment can have an impact on the corporate world as a whole or certain developed in the company. This competition can be the positive and negative-impact on the performance of the related industries. In terms of opportunities for business enhanced the negative impacts affects the threats to its business or even the existence of the business. Industry environmental analysis was conducted to determine the level of competition in the tomato agribusiness industry, by using the 
framework of Porter, which states the level of competition in the industry.

Competition in the retail industry continues to increase puts pressure on suppliers in handling customer requests. Nowadays, most companies make greater efforts to improve customer satisfaction by trying to understand more about the behavior and segmentation of customers into homogeneous groups. Individual behavior allows multiple pricing strategies to maintain customer satisfaction at the maximum level, and some customer behavior factors influencing their purchasing decisions covering needs or demands, loyalty, and price sensitivity (Bushman, Hendricks, \& Williams, 2016; and Tutwiler, 2016).

\subsection{Threat of New Entrants}

This is an important structural component with industry to restrict or prohibit the entry of new-competitors. The main component is customer loyalty, product differentiation, cost of investment, access to distribution channels, and policy (Indiatsy, Mwangi, Mandere, Bichanga, \& George, 2014; Dalken, 2014; Arons \& Waalewijn, 1999; Cafferky, 2005; and Bushman et al., 2016).

In an industrial environment, the interaction to five parts of the industry-environment will bring the capacity of the company concerned to try to seize the market. Hurdles' newcomers who will affect the level of competition within an industry, which is in the form of economies of scale, product differentiation tomatoes, capital needs, access to distribution channels, cost structure and government policy (Aktouf, 2004).

Companies need a big budget in its efforts to use new-technologies and promotion costs. The use of new technology will be managed to improve its performance in the market environment. While fewer communicative promotions will be threatened as more competitors enter the market. Duplication technology as well as the current product will be commonplace in the competitive market. Companies today spend more funds will be used for research and development of new products, as new-products are forced to mature by early stage in his or her life cycle (Mathooko, \& Ogutu, 2015; and Indiatsy, Mwangi, Mandere, Bichanga, \& George, 2014).

\subsection{Bargaining Power of Buyers}

Competition among the tomato industry can occur because of the decline in prices, bargaining for higher quality and better waiters and act as competitors with each other. Buyer bargaining power depends on the size order buyers, sensitivity prices, the level of product differentiation, switching cost, knowledge of the buyer (Mathooko, \& Ogutu, 2015; Dalken, 2014; Cafferky, 2005; and Bushman et al., 2016).

No business can succeed without a loyal customer. The profitability of the business is as a result of the creation of value between what has been sold by a seller and what has been purchased by the buyer. No impairment proportionally, when the buyer or the customer has the bargaining power is higher than the seller. Company's often left customers high purchasing power but pay less for the products offered. This will result in lower profits for businesses that leave customers with high purchasing power. If this situation is not addressed, it will worsen the company's performance, and the situation will increase the demand for 
goods (Progress, Whilhemia, and Tarisai, 2013).

\subsection{Bargaining Power of Tomato's Supplier}

Bargaining power of suppliers in the tomato industry relies heavily on a lot or not the large number of suppliers. The power factor bargaining-supplier is a concentration of suppliers, the level of relations with suppliers, the degree of differentiation, and the cost of the transition (switching cost) supplier (Progress et al, 2013; Bushman et al., 2016; Cafferky, 2005; and Arons \& Waalewijn, 1999),

\subsection{Competitive Rivalry}

Competition-among producers of tomatoes include the number of competitors, the differences in quality, customer loyalty, and the price difference (Dalken, 2014). In the industrial-world, competition between manufacturers will be more stringent, especially if the industry consists of only a few producers. Aggressiveness will depend on several key factors, which include: The number of competitors; developed growth; High fixed costs; Differentiation; Production capacity; The diversity of competitors and business strategy unit (Indiatsy et al, 2014; Cafferky, 2005; and Arons \& Waalewijn, 1999).

Competition occurs primarily when companies offer similar products on the market. An organization losing his grip on power because customers tend to choose other companies for the same products when they feel they are paying more than what they get. This happens because of competition arises when there are more entrepreneurs or producers involved in the supply and demand of products, where the level of the higher demand accompanied with a limited consumer purchasing power (Dalken, 2014; and Mathooko, \& Ogutu, 2015).

\subsection{Threat of Substitutes}

The presence of tomato products similar in the collector and the existing ones in the market with cheaper prices and a tendency to be higher-quality. Factors' threat of substitute products is the ease of getting a replacement product. The price offered replacement products, and product replacement costs' replacement of local tomatoes with tomato imports (Dalken, 2014; and Progress et al, 2013).

The replacement product is known as a major threat to the substitution of regional tomato products. If the deals involving imported tomato products permitted by the government with better quality and cheaper price (Indiatsy et al, 2014; Dalken, 2014; Bushman et al., 2016; and Cafferky, 2005).

\section{Methodology}

This research was conducted around the tomato plantations, Cameron Highland, Malaysia. The study was conducted from 10 September 2014 to 25 September 2015, and 250 questionnaires distributed purposively and structured distributed to producers of tomatoes, organizations and entities associated in the field of distribution and sale of tomato, which include collectors, businesses, suppliers, importers, traders of associations' tomatoes, department of agriculture, department of commerce, supermarkets, traditional markets, 
consumers and agribusiness experts.

This research was conducted in three (3) phases: The first phase, which includes a preliminary study conducted in September and December 2015. In this phase, carried out literature studies and search related information relevant to producers, related organizations, customers, and suppliers' market tomato; Second, the study was conducted from January to May 2016. The research phase of this data collection and information that suits the purpose of research; and Third, arrange focus group discussion on the tomato market competition and tabulation conducted from June to September 2015.

The data collected were tabulated by using content analysis - SAS text miner, which focuses on ideal and current of industry competition (Indiatsy et al, 2014; Progress et al, 2013; Arons \& Waalewijn 1999; Aktouf, 2004; Bushman et al., 2016; Mathooko, \& Ogutu, 2015; and Cafferky, 2005): The threat from new entrants; Buyer bargaining power; Bargaining power of suppliers; Competition among suppliers; The threat from substitute products and tomatoes from countries (regions) other (Toro-Jarrín, Ponce-Jaramillo, \& Güemes-Castorena, 2016).

\section{Results and Discussion}

The results are based on industry competition tabulation (Table 1) indicating that the tomato industry competition in Cameron Highland-significant $(\mathrm{CA}=0.7136)$. The threat of substitute products' tomatoes from other regions or import is very significant or nearly $60 \%$ of Thailand's production of tomatoes that supplied to Malaysia. This factor influences the access of getting a tomato or a replacement product from Thailand, and they more competitive or cheaper than Cameron's tomato products. The replacement cost of local-tomatoes is lower than the imported one from Thailand. It is because the tomato is readily available throughout the supermarket and traditional market in the peninsula Malaysia.

Table 1. Existing Competition tomato market in Cameron Highland, Malaysia

\begin{tabular}{|l|l|l|}
\hline Market Force & Value & \% Freq \\
\hline Threat of new entrants & 32 & 0.1916 \\
\hline Power of Buyers & 37 & 0.2216 \\
\hline Power of Suppliers & 31 & 0.1856 \\
\hline Rivalry among existing competitors of Tomatoes & 28 & 0.1677 \\
\hline Substitutes of Tomatoes & 39 & 0.2335 \\
\hline
\end{tabular}

Content Analysis $=\mathrm{CA}=0.7136$

Ideal competition (Table 2) indicated that rivalry among existing competitors of tomatoes needs to be improved or became open competition. It would develop market perfect competition (Table 3). Moreover, substitute of tomatoes is so dominant (over expectation). This situation enhanced bargaining power of buyers as well as a threat of new-entrants. It was proved by the indicator of power of buyer frequency gaps (-0.0153), and the existing of a threat of a new entrants' frequency gaps is bigger than its ideal competition. As mentioned before, bargaining power of suppliers is so dominant or over expectation, and this situation 
made suppliers would control customers driven.

Significant bargaining power buyers, because buyers easily choose and buy tomatoes in various supermarkets and traditional markets with competitive price and fresh tomatoes. A tomato's price ranges on retailers' market is from 0.5 to 1 USD per $\mathrm{kg}$. They can obtain tomato freely from different suppliers both from local suppliers, regional, and international such as Thailand and Indonesia's countries. Thailand is a threat of new entrants who have high accessibility of land, which is between Bukit Kayu Hitam (Malaysia) and Sadao (Thailand).

Table 2. Ideal Competition tomato market in Cameron Highland, Malaysia

\begin{tabular}{|l|l|l|}
\hline Market Force & Value & \% Freq \\
\hline Threat of new entrants & 29 & 0.1813 \\
\hline Power of Buyers & 33 & 0.2063 \\
\hline Power of Suppliers & 28 & 0.1750 \\
\hline Rivalry among existing competitors of Tomatoes & 36 & 0.2250 \\
\hline Substitutes of Tomatoes & 34 & 0.2125 \\
\hline
\end{tabular}

Content Analysis $=\mathrm{CA}=0.7273$

Table 3. Gaps Competition tomato market in Cameron Highland, Malaysia

\begin{tabular}{|l|l|l|l|}
\hline Market Force & Existing & Ideal & Freq Gaps \\
\hline Threat of new entrants & 0.1916 & 0.1813 & -0.0104 \\
\hline Power of Buyers & 0.2216 & 0.2063 & -0.0153 \\
\hline Power of Suppliers & 0.1856 & 0.1750 & -0.0106 \\
\hline Rivalry among existing competitors of Tomatoes & 0.1677 & 0.2250 & 0.0573 \\
\hline Substitutes of Tomatoes & 0.2335 & 0.2125 & -0.0210 \\
\hline
\end{tabular}

The threat of unknown tomato producers either from Malaysia or from the country of Thailand became an important structural component with tomato industry. Since there is no restriction on the entry of new competitors in the market tomato industry. The main component is the threat of a brand-new manufacturer of customer loyalty, product differentiation, cost of investment, access to distribution channels, and policy.

In a tomato's industrial-environment, the interaction of five parts of the capacities of the company that concerned to try and to seize the market. A new-producer obstacle that will affect the level of competition in the tomato industries' market, namely in the form of economies of scale, product differentiation of tomatoes, capital needs, access to distribution channels, cost structure, and government policies.

Producers of tomatoes require a large budget in his efforts to use new technology and promotion. The use of brand new technology will be managed to improve its performance in the market environment. While fewer communicative promotional costs will be threatened as 
more competitors enter the market in the competitive market. Companies today spend more funds used for research and development of fresh tomato seed products, as modern products are forced to mature by early stage in their lives' cycle.

Bargaining power of suppliers is quite significant, because it is done by the producer. Buyer bargaining power factor tomatoes are very dependent on the magnitude order of buyers, price sensitivity, the level of product differentiation, switching cost or replacement cost of suppliers. Buyers will know tomato products. Price's sensitivity is very dominant. The indicator, based on the price comparison, we can see a significant difference between the farm price to consumers. The price difference is due to expenses such as transportation such as trucks, storage in the cold room and packaging activities that involve two or more intermediaries (distributors / retailers) to bring these tomatoes to the market. We can see that the distributors have greater bargaining power in determining industry competition because he is faced with a large number of intermediaries to be selected. The structure of competition among manufacturers over the lead position of farmers locked in power distributor or intermediary is very significant.

Competition among producers of tomatoes is not so significant. It includes the number of competitors, the differences in quality, customer loyalty, and the difference in price. In the tomato industry, competitions between tomato producers are increasingly stringent, particularly if the industry consists of only a few producers. Aggressive competition between producers of tomato will depend on several key factors, which include: The number of competitors' tomatoes; Growth tomato industry; Differentiation; Tomato production capacity; diversity of competitor's business strategy unit tomatoes; and High fixed costs and tomatoes, which greatly affect the selling price of tomatoes. The indicators, pricing tomatoes in Camerion Highland usually made consignment. This sales system has the risk of price changes to be borne by the manufacturer. This form of uncertainty in the market price, the presence of the bond loan and also the confidence of farmers to distributors.

In the context of the marketing or distribution of tomato suppliers, distribution channel starting from the collection at the farm level to distributors and retailers. This practice depends on factors' relationship between market intermediaries and farmers in an area. This distribution system is patterned on the role played by distributors in farms and distributors in the market. Good competition can be seen at the retail level. In the production of tomatoes, intermediaries play an important role in ensuring traders get supplies at the required time and ensure adequate supply of tomatoes. Market intermediaries sometimes share more than one task. Intermediaries can become a distributor and also in the same time is a retailer.

Furthermore, imports of goods and high food production need to be patterned tradition globally to allow vegetable output Malaysia competed in the market. For commodities' tomatoes, concentration in terms of large-scale production and the mechanism of high-tech industrial plants, private-sector involvement, is a challenge that needs to be addressed seriously. One reform the pattern of cultivation and production need to be implemented to generate a scheduled production and meet market demand.

In the context of the distribution strategy, marketing strategies of tomatoes in Malaysia 
generally use e-commerce and alliances. The development in information technology and the Internet would be a better opportunity for farmers to farmers since directly to the supermarket or to supply tomatoes to the market. Indirectly, the role of an intermediary can be reduced. Thus, the price of tomatoes is not manipulated by them. Moreover, farmers can plan for the future market production. TaniNet became an interactive site that should be a new method for marketing agricultural-products in e-commerce that enables agricultural products' direct selling without involving intermediaries or collectors. In addition, the site provides agricultural-information such as education and training, advice and consultation, discussion and opportunities to search the site to carry out e-commerce.

Furthermore, the formation of strategic alliances between the supermarket and tomato farmers' premiere as Tesco, Giant, or MACRO, where pseudo supermarkets this inaugural exists throughout Malaysia. So, indirectly, Malaysia's tomato industry can be marketed overseas through this channel (Rittgers, 2014; and Nawawi \& Nasir, 2014).

From the results of field research, it appears, there are the efforts of farmers to improve the performance of tomatoes by increasing packing-technology, and how altered tomato packing of the packing material in bulk into a smaller form. For example, using plastic baskets, boxes of paper or cardboard in a small quantity which is easily handled and transported to reduce fruit damage. Demonstration of products to be shipped to markets should be emphasized the cleanliness and size of tomatoes. This is done because there is more demand for a fresh tomato and for healthy food it has increased in both the export and domestic markets in Malaysia. Farmers with large-scale production, the practice of good agricultural practices, has managed to increase the income up to 1.7 times. Through quality tomato exports compared to minor farmers who produce tomatoes without practicing. Besides small-scale farmers do not have access to credit for investment, and technical support (Islam, Arshad, Radam, and Alias, 2012).

In 2011, the production of tomatoes in Malaysia, mostly from tomato plantation area of 1,354 hectares. The main commercial tomato production in Malaysia is concentrated in Cameron Highlands, Pahang and Sabah. Until now, the demand for healthy tomato and safety has increased in both the export and domestic markets in Malaysia. However, a shortage of supply of tomatoes for intensive demand from local and export market requires more tomato cultivation in Malaysia (Najwa, Zaliha, Yusnita, \& Zuraida, 2014).

In recent years, festination is a cultural system the most widely used in growing tomatoes. Culture technique is a growing system that eliminates the use of land in cultivation (Nawawi \& Nasir, 2014). The purpose of using the planting medium is more likely to avoid soil diseases and pests.

In the context of the international market, the power of a supplier of tomato sauce from several countries such as: (a) Singapore, which supplied her with Asian sauce competitive price with high quality such as "Satay" spices and sauce chicken rice; (b) China into a great supplier of high-quality Asian-sauces such as chicken rice sauce, oyster sauce and plum sauce; (c) Thailand was the main supplier of fish sauce and chili sauce; and (d) the United States is a major supplier of western dressing as a salad dressing, spaghetti sauce, seasoning mix, 
barbecue sauce, black pepper sauce, a variety of salad cream sauces and a spicy tomato sauce.

Furthermore, the strength of the Thai state as a supplier of tomatoes excels in the provision of pineapple juice, cordials and drinks in Asia and other non-alcoholic beverages. United States is the largest supplier of tomato juice and mixed fruit or vegetable juice to Malaysia with products like Welch, Del Monte, Minute Maid, Ocean Spray.

\section{Conclusions}

The study found that the tomato industry competition in Cameron Highland is significant. The indicators, the strength of the bargaining power of consumers is greatly high, and product replacement of newcomers from neighboring Thailand also so dominant because of the accessibility of distribution and land transportation is very supportive.

The threat of substitute product's tomatoes from other regions or import is very significant. Nearly $60 \%$ of production of tomatoes from Thailand supplied to Malaysia. Factor that influence is the ease of getting tomatoes from Thailand, and the price offered by producers of tomatoes from Thailand is very competitive or much cheaper than tomato products from Cameron Highland. The indicators, these tomatoes are readily available throughout the super-market and traditional market in a peninsula Malaysia.

On the other hand, distributors have greater bargaining power in determining the market because he is faced with a large number of intermediaries to be selected. The industrial structure above causes the position of farmers locked in power distributor or intermediary is great.

However, the development of information technology and the Internet becomes a chance for farmers to farmers since continued to a supermarket to supply tomatoes to the market. Indirectly, the role of an intermediary can be reduced. Thus, the price of tomatoes is not manipulated by them. In addition, farmers can plan for the future market production.

\section{Implication}

In the context of the distribution strategy, although the tomato industry competition is very significant, but the marketing of tomatoes in Malaysia, which began using e-commerce strategy and alliances is supporting the price information to farmers who are connected directly to the supermarket or to the market. Indirectly, the role of an intermediary can be reduced. Thus, the price of tomatoes is not manipulated by them.

Nevertheless, the outcomes from this study indicated that its need further more at least two domains of the research: Firstly, analyzing in international or regional marketing strategy on responding global market competition that influence by international-trading, supply chain and demand.

Secondly, the other topic of the possibility is about the value chain analysis. Since there are so many sub-topics, its need more funding and research team on conducting value chain of tomatoes' industry on distributing and tackling the responsive demand within two countries that enhanced tomatoes' farmers income every year. 


\section{References}

Aktouf, K. (2004). The false expectations of Michael Porter's strategic management framework. Revista Universidad \& Empresa, 6(6), 9-41

Arons, H. S., \& Waalewijn, P. (1999). A knowledge base representing Porter's five forces model, RePub, Erasmus University, 2-8

Bushman, R., Hendricks, B., \& Williams, C. D. (2016). Bank Competition: Measurement, Decision-Making, and Risk-Taking. https://doi.org/10.1111/1475-679X.12117

Cafferky, M. E. (2005). The Porter five-forces industry analysis framework for relegious nonprofits: A conceptual analysis, Point Loma Nazarene University. Retrieved from http://www.cbfa.org/Cafferky2.pdf

Dalken, F. (2014). Are Porter's five competitive forces still applicable? A critical examination concerning the relevance for today's business, Bachelor thesis, University of Twente, Faculty of Management and Governance, 1-5

Hoh, K. S. (2014). Bumper crop leads to tomato glut in Cameron Highlands, The sun daily. Retrieved from http://www.thesundaily.my/news/1032978

Indiatsy, C. M., Mwangi, M. S., Mandere, E. N., Bichanga, J. M., \& George, G. E. (2014). The Application of Porter's Five Forces Model on Organization Performance: A Case of Cooperative Bank of Kenya Ltd, European Journal of Business and Management, 6(16), 75-85. Retrieved from www.iiste.org

Islam, G. M. N., Arshad, F. M., Radam, A., \& Alias, E. F. (2012). Good agricultural practices (GAP) of tomatoes in Malaysia: Evidences from Cameron Highlands, African Journal of Business Management, 6(27), 7969-7976. https://doi.org/10.5897/AJBM10.1304

Mathooko, F. M., \& Ogutu, M. (2015). Porter's five competitive forces framework and other factors that influence the choice of response strategies adopted by public universities in Kenya, International Journal of Educational Management, 29(3), 334-354.

http://dx.doi.org/10.1108/IJEM-12-2013-0187

Najwa, K. A. A., Zaliha, W.S. W., Yusnita, H., \& Zuraida, A. R. (2014). Postharvest Performance and Physico-Chemical Changes of Two ashew Apple (Anacardium occidentale L.) Cultivars at Different Maturation Stages, Trans. Malaysian Soc. Plant Physiol, 22, 58-62. Retrieved from http://www.mspp.org.my/files/ FullPapers_TransactionMSPPVol22.pdf

Nasir, B., \& Nawawi, N. (2014). Fama rescues tomato farmers. New Straits Times. Retrieved from http://www2.nst.com.my/opinion/columnist/fama-rescues-tomato-farmers-1

Nawawi, N., \& Nasir, B. (2014). Fama rescues Cameron Highlands' tomato farmers

Porter, M. E. (2008). The five competitive forces that shape strategy, Harvard Business Review, 86(1), 32-78

Porter, T. (2016). States, Markets and Regimes in Global Finance, St. Martin's Press, 44-46. 
https://doi.org/10.1007/978-1-349-27890-9

Progress, H., Whilhemia, S., \& Tarisai, C. (2013). The Delineation of Porter's Five Competitive Forces Model from a Technological Marketing Perspective: A Case Study of Buffalo City Metropolitan Municipality, Journal Economics, 4(2), 169-182. http://www.krepublishers.com/02-Journals/JE/JE-04-0-000-13-Web/JE-04-2-000-13-Abst-PD F/JE-04-2-169-13-104-Progress-H/JE-04-2-169-13-104-Progress-H-Tt.pdf

Rittgers, C. P. (2014). Malaysia Retail Food, Gain report, 19-25. Retrieved from http://gain.fas.usda.gov/Recent\%20GAIN\%20Publications/Retail\%20Foods_Kuala\%20Lump ur_Malaysia_11-19-2014.pdf

Toro-Jarrín, M., A., Ponce-Jaramillo, I. E., \& Güemes-Castorena, D. (2016). Methodology for the of building process integration of Business Model Canvas and Technological Roadmap, Technological Forecasting and Social Change, 110, 213-225.

http://dx.doi.org/10.1016/j.techfore.2016.01.009

Trading Economics (2016). Malaysia GDP per capita, Trading Economics. Retrieved from http://www.tradingeconomics.com/malaysia/gdp-per-capita/forecast

Tutwiler, M. A. (2016). U.S. Agriculture in a Global Setting: An Agenda for the Future, Routledge, Business \& Economics, 113-115.

\section{Copyright Disclaimer}

Copyright for this article is retained by the author(s), with first publication rights granted to the journal.

This is an open-access article distributed under the terms and conditions of the Creative Commons Attribution license (http://creativecommons.org/licenses/by/3.0/). 